\title{
PENGARUH INTELLECTUAL CAPITAL TERHADAP KINERJA KEUANGAN DAN PERTUMBUHAN PERUSAHAAN
}

(Studi Kasus Pada Perusahaan Konstruksi Yang Terdaftar Di BEI Tahun 20112013)

\author{
Silviana Agustami \\ Adrian Rahman \\ (Universitas Pendidikan Indonesia)
}

\section{ABSTRACT}

The research aims to determine how the influence of intellectual capital which measured by Value Added Intellectual Coefficient (VAIC) to finance performance which measured by Return on Asset (ROA) and Return on Equity $(R O E)$ and to Firm Growth which measured by Asset Growth (AG) and Equity Growth (EG), in construction companies listed on the Indonesia stock exchange (IDX) 2011-2013 period .The sampling using purposive sampling method, the samples was taken from 7 companies. This research used secondary data, which means the data that used in this research come from annual report of company and is used smartPLS 3.0 to analysed the data. This research show that there is positive influence between intellectual capital to financial performance and intellectual capital also has positive influence to firm growth.

Keywords : intellectual capital, Value Added Intellectual Coeffisient (VAIC), ROA, ROE, AG, EG.

\section{PENDAHULUAN}

Indonesia merupakan negara berkembang, perkembangan tersebut terjadi di berbagai bidang, salah satunya adalah pembangunan. Pembangunan yang dilakukan untuk menunjang sarana dan prasarana yang dibutuhkan oleh masyarakat, seperti infrastruktur dan sarana transportasi baik itu dilakukan oleh pihak pemerintahan maupun pihak swasta. Menurut data dari Kementrian Pekerjaan Umum pertumbuhan sektor konstruksi diperkirakan dapat mencapai 10\% - 15\% seiring program Masterplan Percepatan dan Perluasan Pembangunan Ekonomi Indonesia (MP3EI) hingga 2025. Hingga saat ini rata-rata pertumbuhan sektor tersebut per tahun mencapai 7\% - 8\%. Dari keadaan tersebut, maka dapat disimpulkan bahwa industri konstuksi merupakan salah satu industri yang menjanjikan hingga 10 tahun kedepan.

Laporan statistik konstruksi 2013 disusun berdasarkan survei terhadap lebih dari 12.000 perusahaan konstruksi di seluruh Indonesia. Kepala Badan Pusat Statistik periode 2009-2014,Suryamin mengatakan "secara total, hingga akhir 2012 lalu terdapat 130.615 perusahaan konstruksi di Indonesia. Jumlah tersebut menyusut dibanding 2011 yang mencapai 134.004 perusahaan. Ketatnya kompetisi menjadi penyebab menyusutnya jumlah tersebut. Tapi jumlah pekerja pada 2012 naik. Artinya bisnis tumbuh. Data produk domestik bruto (PDB) sektoral BPS menunjukan, dalam beberapa tahun terakhir, pangsa sektor 
konstruksi dalam PDB Indonesia terus naik, pada 2008 porsinya hanya 6.3\% pada tahun 2012 sudah naik hampir dua kali lipat hingga 11.6\%". (http://www.jpnn.com diakses 10 November 2014).

Penurunan tersebut disebabkan perusahaan tidak mampu bertahan dalam persaingan. Ditambah dengan perusahaan konstuksi-konstuksi tersebut harus bersaingan dengan perusahaan konstruksi berplat merah yaitu perusahaan konstruksi BUMN, membuat perusahaan konstruksi kecil menengah sulit untuk berkembang. Seperti yang disebutkan oleh Joko oryxahadi, ketua gabungan pelaksanaan konstruksi nasional Indonesia (Gapensi) Jawa tengah periode 20122017, dalam sebuah lelang, "terkadang perusahaan konstruksi kecil berhadapan dengan perusahaan konstruksi besar, semisal dari Badan Usaha Milik Negara.( http://www.tempo.co Diakses 12 November 2014).

Untuk dapat bertahan dan terus tumbuh, perusahaan harus membuat strategi bisnis yang baik. Diperlukan penyesuaian dari strategi yang didasarkan pada tenaga kerja (labor based business) menjadi strategi yang berdasarkan ilmu pengetahuan (knowledge). Makin kompetitifnya lingkungan konstruksi di Indonesia menuntut setiap perusahaan untuk mampu beradaptasi dan tetap bertahan untuk bisa terus hidup. Untuk itu setiap perusahaan harus mempunyai keunggulan kompetitif yaitu melalui kepemilikan atas sumber daya yang dapat menciptakan nilai bagi perusahaan, sulit ditiru, bersifat langka, dan tidak memiliki substitusi (Barney 1991 dalam Anatan 2003).

Banyak faktor yang dapat membuat perusahaan itu lebih kokoh dimata pasar yang bukan saja berasal dari aset fisik yang dimiliki, walaupun itu sangat penting, namun juga dari aset tidak berwujud. Aset yang tidak berwujud tersebut seperti jumlah equity, kekuatan pada finansial performance, kemampuan intelektual perusahaan, efisiensi biaya yang meningkatkan kinerja keuangan perusahaan dan kekuatan perusahaan untuk bersaing, hingga inovasi secara terus menerus. Aset tak berwujud ini juga disebut sebagai intellectual capital atau modal intangible yang dapat meningkatkan financial performance dan competitiveness perusahaan (Margaretha dan Rakhman 2006).

Kemampuan manajemen dalam memanfaatkan nilai yang terdapat dalam aktiva yang tidak berwujudlah yang akan menentukan prospek bisnis perusahaan. Dalam lanskap kempetitif bahwa sumber daya tidak berwujud lebih memungkinkan untuk menghasilkan keunggulan kompetitif karena mereka seringkali benar-benar langka dan dapat lebih menyulitkan bagi pesaing untuk meniru (Blak \& Boal, 1994; Itami, 1987; Rao, 1994 dalam DeNisi et at, 2003). Keunggulan kompetitif yang berkelanjutan dari waktu ke waktu mengarah pada kinerja yang lebih tinggi (Pereraf, 1993 dalan DeNisi et al, 2003).

Menurut Barney (1991) dalam Njuguna (2009) suatu perusahaan dikatakan dapat memiliki keunggulan kompetitif yang berkelanjutan ketika perusahaan tersebut mengimplementasikan sebuah strategi penciptaan nilai yang tidak secara bersamaan diimplementasikan oleh kompetitor potensial dan ketika perusahaan 
lain tidak dapat untuk meniru keunggulan dari strategi ini. Ini adalah alasan mengapa organisasi fokus pada metode dan strategi yang sulit untuk ditiru. Salah satu dari metode dan strategi itu adalah pembelajaran organisasi dalam kemampuannya mengelola modal intelektual.

Modal intelektual pada dasarnya adalah perbedaan antara nilai pasar perusahaan dengan nilai aset perusahaan atau dari financial capitalnya. Hal ini berdasarkan suatu observasi bahwa sejak akhir 1980-an, nilai pasar dari bisnis kebanyakan dan secara khusus adalah bisnis yang berdasarkan pengetahuan telah menjadi lebih besar dari nilai yang dilaporkan dalam laporan keuangan berdasarkan perhitungan yang dilakukan oleh akuntan. Selisih tersebut menunjukan adanya hidden value yang tidak diungkapan dalam laporan keuangan, yang kemudian disebut sebagai intellectual capital. Oleh karena itu intellectual capital merupakan faktor penting yang dapat meningkatkan nilai suatu perusahaan terutama pada perusahaan yang berbasis pengetahuan (Ulum, 2009).

Pulic (1998) mengajukan suatu ukuran untuk menilai efisiensi dari nilai tambah sebagai hasil dari kemampuan intelektual perusahaan (value added intellectual coefficient- VAIC). Komponen utama dari VAIC dapat dilihat dari sumber daya perusahaan yaitu, physical capital (VACA- value added capital employed), human capital(VAHU- value added human capital), dan structural capital (STVA- structural capital value added). Menurut Pulic (1998) tujuan utama dari ekonomi berbasis pengetahuan adalah untuk menciptakan value added, sedangkan untuk dapat menciptakan value added dibutuhkan ukuran yang tepat tentang physical capital dan intellectual potential.

Selain itu, Appuhami(2007) menyatakan bahwa semakin besar nilai modal intelektual(VAIC) suatu perusahaan, maka semakin efisien penggunaan modal perusahaan tersebut dalam menciptakan value added bagi perusahaan. Physical Capital sebagai bagian dari modal intelektual menjadi sumber daya yang menentukan kinerja perusahaan. Selain itu, jika modal intelektual merupakan sumber daya yang terukur untuk peningkatan competitive advantages, maka modal intektual akan memberikan kontribusi terhadap kinerja perusahaan. Modal intelektual diyakini dapat berperan penting dalam peningkatan nilai perusahaan maupun kinerja keuangan. Perusahaan yang mampu memanfaatkan intellectual capital secara efisien, maka nilai pasar dan kinerja perusahaannya akan meningkat.

Menurut Triwidodo (1997), tujuan suatu perusahaan adalah mempertahankan kelangsungan hidup, melakukan pertumbuhan, serta meningkatkan profitabilitas. Ketiga tujuan ekonomis tersebut merupakan pedoman arah strategis semua organisasi bisnis. Perusahaan yang tidak mampu bertahan hidup tidak akan mampu memberi harapan kepada pihak-pihak yang berkepentingan.

Kinerja keuangan dalam penelitian ini dilihat dari profitabilitas yang diukur dengan rasio Return on Equity (ROE) dan Return on Asset (ROA) 
sedangkan untuk pertumbuhan perusahaan diukur dengan Asset Growth (AG) dan Equity Growth (EG). ROE merupakan ukuran profitabilitas dilihat dari sudut pandang pemegang saham dan ROA adalah ukuran profitabilitas dari penggunaan total aktiva. Sedangkan pertumbuhan AG dan EG menggambarkan pertumbuhan perusahaan yang akan mempengaruhi profitablitas dan pertumbuhan yang akan datang. (Taswan, 2003)

Berdasarkan latar belakang di atas, maka peneliti tertarik untuk mengambil

judul "Pengaruh Intellectual Capital terhadap Kinerja Keuangan dan Pertumbuhan Perusahaan (Studi pada perusahaan konstruksi yang terdaftar di BEI 2011-2013)".

Berdasarkan uraian di atas, maka tujuan penelitian ini adalah sebagai berikut ; (1) Mengetahui apakah intellectual capital berpengaruh positif terhadap kinerja keuangan perusahaan dan (2) Mengetahui apakah intellectual capital berpengaruh positif terhadap pertumbuhan perusahaan.

\section{KAJIAN PUSTAKA}

The Resource-Based Theory (RBT) membahas mengenai sumber daya yang dimiliki oleh perusahaan, dan bagaimana perusahaan dapat mengembangkan keunggulan kompetitif dari sumber daya yang dimilikinya, Wernerfelt (1984) dalam Chen et al (2005) menyatakan bahwa dalam teori RBT ini, untuk mengembangkan keunggulan kompetitif perusahaan harus memiliki sumber daya dan kemampuan yang superior dan melebihi para kompetitornya.

VAIC merupakan metode yang dikembangkan oleh Pulic pada tahun 1998 yang didesain untuk menyajikan informasi mengenai value creation effiency dari aset berwujud (tanggible asset) dan aset tidak berwujud (intengible asset) yang dimiliki perusahaan. Model ini dimulai dengan kemampuan perusahaan untuk menciptakan value added (VA). Menurut Pulic (1998), VA adalah indikator paling objektif untuk menilai keberhasilan bisnis dan menunjukan kemampuan perusahaan dalam penciptaan nilai (value creation) (dalam Ulum, 2009:86).

Komponen utama dari VAIC yang dikembangkan oleh Pulic(1999) adalah; Physical capital (VACA - Value Added Capital Employed), human capital (VAHU - Value Added Human Capital), dan structural capital (STVA Structuran Capital Value Added).

VACA adalah indikator untuk value added yang diciptakan oleh satu unit dari physical capital terhadap value added perusahaan. VACA adalah perbandingan antara value added (VA) dengan model fisik yang bekerja (CA). Dalam proses penciptaan nilai, intelektual potensial yang direpresentasikan dalam biaya karyawan tidak dihitung sebagai biaya (input) (Tan et al., 2007:79 dalam Ulum 2009:89).

VAHU mengindikasikan berapa banyak Value Added (VA) dapat dihasilkan dengan dana yang dikeluarkan untuk tenaga kerja pegawai (Tan et al., 2007:79 dalam Ulum 2009:88). Human capital merepresentasikan kemampuan 
perusahaan dalam mengelola modal pengetahuan individu organisasi yang dipresentasikan oleh karyawannya sebagai asset strategic perusahaan karena pengetahuan yang mereka miliki. Hubungan antara VA dengan HC mengindikasikan $\mathrm{HC}$ untuk menciptakan nilai di dalam perusahaan.

Structural Capital Value Added (STVA) menunjukkan kontribusi modal struktural yang dibutuhkan untuk menghasilkan 1 rupiah dari value added perusahaan. Dalam model yang dikembangkan Pulic ini, STVA dihitung dengan membagi structural capital (SC) dengan value added (VA). Dalam model Pulic, SC diperoleh dari VA dikurangi dengan HC. STVA menunjukkan kontribusi modal struktural dalam penciptaan nilai semakin kecil kontribusi HC dalam penciptaan nilai maka akan semakin besar kontribusi SC (Tan et al., 2007 dalam Ulum, 2009:88).

Kinerja keuangan perusahaan merupakan ukuran dari keadaan keuangan perusahaan dalam periode waktu tertentu dan gambaran atas kondisi keuangan sebuah perusahaan. Perusahaan yang dapat memaksimalkan sumber daya yang berada di dalam perusahaan maka perusahaan tersebut dapat menciptakan nilai tambah dan keunggulan kompetitif yang berpengaruh terhadap peningkatan financial performance (Sawir, 2005:129).

Pengukuran terhadap kinerja keuangan perusahaan sangat diperlukan dalam relasi dengan kepuasan konsumen, proses internal, dan aktivitas yang berhubungan dengan perbaikan dan inovasi dalam organisasi yang membawa future financial return (Anatan, 2004). Untuk mengukur kinerja keuangan dalam penelitian ini menggunakan Return on Asset (ROA) dan Return on Equity (ROE).

Pertumbuhan perusahaan merupakan kemampuan perusahaan untuk meningkatkan size (Kallapur dan Trombey, 1999) dalam Solikhah (2010). Tingkat pertumbuhan perusahaan dapat dinilai dari beberapa segi, di antaranya adalah peningkatan aktiva, peningkatan laba, peningkatan ekuitas maupun peningkatan laba. Peningkatan pendapatatn biasanya merupakan sinyal bagi perusahaan untuk dapat tumbuh dan berkembang (Chen et al., 2005).

Weston dan Copeland (1997:196) mengatakan bahwa pertumbuhan perusahaan mengukur seberapa baik perusahaan mempertahankan posisi ekonominya, baik dalam industrinya maupun dalam kegiatan ekonomi secara keseluruhan. Pertumbuhan menunjukan kemampuan perusahaan dalam mengelola sumber daya yang dimilikinya untuk memperoleh value added yang merupakan salah satu faktor yang menentukan perusahaan untuk tetap survive.

Kerangka pemikiran pada penelitian ini adalah sebagai berikut:

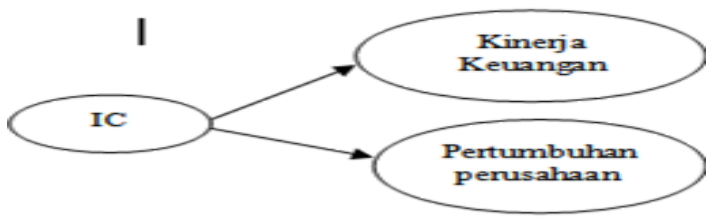

Gambar 1 Kerangka Pemikiran 


\section{Hipotesis}

1. Intellectual Capital berpengaruh positif terhadap kinerja keuangan perusahaan.

2. Intellectual Capital berpengaruh positif terhadap pertumbuhan Perusahaan.

\section{METODE PENELITIAN}

Berdasarkan latar belakang dan kerangka pemikiran, maka yang menjadi objek dalam penelitian ini adalah intellectual capital, kinerja keuangan, dan pertumbuhan perusahaan. Peneliti melakukan penelitian pada perusahaan konstruksi yang konsisten terdafar pada Bursa Efek Indonesia tahun 2011-2013. Desain penelitian yang dilakukan pada penelitian ini adalah asosiatif kausal. Menurut Umar (2003) penelitian asosiatif kausal adalah penelitian yang bertujuan untuk menganalisis hubungan antara satu variabel dengan variable lainnya atau bagaimana suatu variabel mempengaruhi variabel lainnya. Dengan kata lain desain kausal berguna untuk mengukur hubungan-hubungan antar variabel riset atau berguna untuk menganalisis bagaimana suatu variabel mempengaruhi variabel yang lain.

\section{Operasional Variabel}

1. Intellectual capital

$\mathrm{VA}=$ OUTPUT - INPUT

$\mathrm{VACA}=\mathrm{VA} / \mathrm{CE}$

$\mathrm{VAHU}=\mathrm{VA} / \mathrm{HC}$

STVA $=$ SC/VA

$\mathrm{VAIC}=\mathrm{VACA}+\mathrm{VAHU}+\mathrm{STVA}$

Output $=$ Total penjualan dan pendapatan lain

Input = Beban (beban bunga dan beban operational) dan biaya lain-lain (selain beban karyawan)

CE : Capital Employed : dana yang tersedia (ekuitas, laba bersih)

$\mathrm{HC}$ : Human Capital (beban karyawan terdiri dari gaji dan tunjangan)

SC : Structural Capital (VA-HC)

\section{Kinerja Keuangan}

ROA $=$ Laba Bersih / Total Aset

ROE : Laba Bersih / Shareholders Equity

3. Pertumbuhan Perusahaan

$\mathrm{AG}=\left(\right.$ Total aktiva tahun $\mathrm{ke}_{\mathrm{t}} \div$ Total aktive tahun $\left.\mathrm{ke}_{\mathrm{t}-1}\right)-1 \times 100 \%$

$\mathrm{EG}=\left(\right.$ laba tahun $\mathrm{ke}_{\mathrm{t}} \div$ Laba tahun $\left.\mathrm{ke}_{\mathrm{t}-1}\right)-1 \times 100 \%$

\section{Populasi dan Sampel Penelitian}

Populasi dalam penelitian ini adalah perusahaan konstruksi yang terdaftar pada bursa efek Indonesia (BEI) pada tahun 2011-2013. Pada tahun 2013 jumlah perusahaan yang ada disubsektor konstruksi ada 9 perusahaan. Pengambilan sampel dilakukan berdasarkan metode purposive sampling. Dari kriteria di atas 
maka sampel yang akan digunakan dalam penelitian adalah berjumlah 7 perusahaan.

\section{Jenis dan Sumber Data}

Jenis data yang digunakan dalam penelitian ini adalah data sekunder berupa laporan tahunan perusahaan (annual report) periode 2011-2013 yang terdaftar di Bursa Efek Indonesia (BEI). Laporan tahunan tersebut didapat melalui sumber internet, melalui situs BEI (www.idx.co.id) ataupun website perusahaan yang bersangkutan. Selain itu peneliti juga menggunakan sumber informasi lainnya yang dapat mendukung perolehan data untuk penelitian ini.

\section{Teknik Pengumpulan Data}

Dalam penelitian ini, teknik pengumpulan data dilakukan dengan telaah dokumentasi, yaitu mempelajari dan menganalisis sumber-sumber informasi tertulis atau dokumen-dokumen yang diperlukan dalam penelitian.

\section{Teknik Analisis Data}

Setelah data penelitian terkumpul langkah selanjutnya adalah melakukan analisis data dilakukan dengan menggunakan analisis yang meliputi,

\section{Outer Model / Measurement Model}

Untuk mengukur outer model pada konstruk berbentuk formative, evaluasi model pengukuran dilakukan dengan melihat signifikansi weight-nya. Sehingga uji validitas dan reliabilitas konstruk tidak diperlukan. Untuk memperoleh signifikansi weight harus melalui prosedur resampling (bootstrapping). (Hengki Latan dan Imam Ghozali, 2012:81)

Tabel 1

Outer Weight (Measurement Model) Variabel Intellectual Capital

\begin{tabular}{|c|c|c|c|}
\hline Variabel & $\begin{array}{c}\text { Original } \\
\text { Sample }\end{array}$ & $\begin{array}{c}\text { Standar } \\
\text { d Error }\end{array}$ & $\begin{array}{c}\mathrm{T} \\
\text { Statistics }\end{array}$ \\
\hline $\begin{array}{c}\text { STVA - } \\
>\text { IC }\end{array}$ & -0.190 & 0.711 & 0.267 \\
\hline $\begin{array}{c}\text { VACA - } \\
>\text { IC }\end{array}$ & 0.685 & 0.266 & 2.580 \\
\hline $\begin{array}{c}\text { VAHU - } \\
>\text { IC }\end{array}$ & 0.642 & 0.663 & 0.969 \\
\hline
\end{tabular}

Sumber: Output SmartPLS 3.0 2015

Dari tabel di atas menunjukan bahwa VACA memiliki nilai $t$-statistic paling besar yaitu 2.580, dimana nilai tersebut melebihi nilai t tabel sebesar 1.734. nilai tersebut VACA merupakan indikator yang signifikan. Sedangkan VAHU dan STVA memiliki nilai $t$-statistik di bawah nilai t tabel yaitu sebesar 0.267 dan 0.969 sehingga indikator VAHU dan STVA tidak valid untuk mengukur variabel intellectual capital. 
Tabel 2

Outer Weight (Measurement Model) Variabel Kinerja Keuangan

\begin{tabular}{|c|c|c|c|}
\hline Variabel & $\begin{array}{c}\text { Original } \\
\text { Sample }\end{array}$ & $\begin{array}{c}\text { Standar } \\
\text { d Error }\end{array}$ & $\begin{array}{c}\text { T } \\
\text { Statistics }\end{array}$ \\
\hline $\begin{array}{c}\text { ROA -> } \\
\text { kinerja } \\
\text { keuangan }\end{array}$ & -0.867 & 0.271 & 3.203 \\
\hline $\begin{array}{c}\text { ROE -> } \\
\text { kinerja } \\
\text { keuangan }\end{array}$ & 1.553 & 0.269 & 5.771 \\
\hline
\end{tabular}

Sumber: Output SmartPLS 3.0 2015

Dari tabel di atas menunjukan bahwa nilati $t$-statictic dari masing-masing indikator kinerja keuangan adalah 3.203 untuk ROA dan 5.771 untuk ROE. Nilai tersebut lebih besar dari t tabel yang bernilai 1.734. sehingga ROA dan ROE valid untuk mengukur kinerja keuangan.

Tabel 3

Outer Weight (Measurement Model) Variabel Pertumbuhan Perusahaan

\begin{tabular}{|c|c|c|c|}
\hline Variabel & $\begin{array}{c}\text { Original } \\
\text { Sample }\end{array}$ & $\begin{array}{c}\text { Standar } \\
\text { d Error }\end{array}$ & $\begin{array}{c}\mathrm{T} \\
\text { Statistics }\end{array}$ \\
\hline $\begin{array}{c}\text { AG -> } \\
\text { pertumbuhan } \\
\text { perusahaan }\end{array}$ & 0.837 & 0.427 & 1.958 \\
\hline $\begin{array}{c}\text { EG -> } \\
\text { pertumbuhan } \\
\text { perusahaan }\end{array}$ & 0.273 & 0.497 & 0.549 \\
\hline
\end{tabular}

Sumber: Output SmartPLS 3.0 2015

Dari tabel di atas menunjukan bahwa nilai t-statistic AG sebesar 1.958 yang berarti lebih besar dari t tabel yang bernilai 1.734, sehingga AG valid untuk mengukur pertumbuhan perusahaan. Sedangkan nilai t-statistic EG adalah 0.549 lebih kecil daripada nilai $t$ tabel yang bernilai 1.734, yang berarti bahwa EG tidak valid untuk mengukur pertumbuhan perusahaan.

Untuk indikator yang tidak valid untuk mengukur variabelnya, indikator tersebut harus di eliminasi, dan dilakukan re-calculation, untuk menilai outer modelnya. Berikut adalah hasil dari re-calculation.

Tabel 4

Re-calculation Outer Weight Variabel Intellectual Capital,Kinerja Keuangan, dan Pertumbuhan Perusahaan.

\begin{tabular}{|c|c|c|c|}
\hline Variabel & $\begin{array}{c}\text { Original } \\
\text { Sample }\end{array}$ & $\begin{array}{c}\text { Standar } \\
\text { d Error }\end{array}$ & $\begin{array}{c}\mathrm{T} \\
\text { Statistics }\end{array}$ \\
\hline $\begin{array}{c}\text { AG -> } \\
\text { pertumbuhan } \\
\text { perusahaan }\end{array}$ & 1.000 & 0.000 & \\
\hline
\end{tabular}




\begin{tabular}{|c|c|c|c|}
\hline $\begin{array}{c}\text { ROA -> } \\
\text { kinerja } \\
\text { keuangan }\end{array}$ & -1.047 & 0.343 & 3.049 \\
\hline $\begin{array}{c}\text { ROE -> } \\
\text { kinerja } \\
\text { keuangan }\end{array}$ & 1.622 & 0.280 & 5.792 \\
\hline VACA -> IC & 1.000 & 0.000 & \\
\hline
\end{tabular}

Sumber: Output SmartPLS 3.0 2015

\section{Inner Model}

Inner model, yaitu spesifikasi hubungan antar variabel laten (structural model), disebut juga dengan inner relation, menggambarkan hubungan antar variabel laren berdasarkan teori substantif penelitian, model struktural dievaluasi dengan menggunakan $R$-square untuk variabel laten endogen dengan uji t serta signifikasi dari koefisien parameter jalur struktural.

Untuk melihat nilai pengaruh antar variabel digunakan estimate for path coefficient, yang merupakan nilai koefisien jalur atau besarnya hubungan/pengaruh konstruk laten. Yang dilakukan dengan prosedur Bootrapping. Pendekatan merepresentasi nonparametic untuk precision dari estimasi PLS.

Selanjutnya untuk mengetahui tingkat besaran korelasi dari hasil path coefficient akan ditunjukan sebagai berikut.

Tabel 5

\section{Pedoman Untuk Memberikan Interprestasi Koefisien Korelasi}

\begin{tabular}{|c|c|}
\hline $\begin{array}{c}\text { Internal } \\
\text { Koefisien }\end{array}$ & Tingkat Hubungan \\
\hline 0 & Tidak ada korelasi \\
\hline $0,00-0,25$ & Sangat lemah \\
\hline $0,25-0,5$ & Cukup \\
\hline $0,5-0,75$ & Kuat \\
\hline $0,75-0,99$ & Sangat kuat \\
\hline 1 & Korelasi sempurna \\
\hline
\end{tabular}

Sumber : Sarwono, (2006:107)

Tabel 6

\begin{tabular}{|c|c|}
\multicolumn{2}{c}{ R-Square } \\
\hline Variabel & R-Square \\
\hline $\begin{array}{c}\text { Kinerja } \\
\text { Keuangan }\end{array}$ & 0.831 \\
\hline $\begin{array}{c}\text { Pertumbuhan } \\
\text { Perusahaan }\end{array}$ & 0.093 \\
\hline
\end{tabular}

Sumber: Output SmartPLS 3.0 2015

Tabel di atas menunjukan bahwa variabel kinerja keuangan memiliki nilai $R$-square sebesar 0.831 yang berarti bahwa variabel intellectual capital dapat menjelaskan variabilitas kinerja keuangan sebesar $83,1 \%$ dan nilai $R$-square 
variabel pertumbuhan perusahaan sebasar 0.093 yang berarti bahwa variabel intellectual capital dapat menjelaskan variabilitas pertumbuhan perusahaan sebesar 9,3\%, sisanya dijelaskan oleh variabel lain yang tidak diteliti dalam penelitian ini.

Signifikasi parameter yang diestimasi memberikan informasi yang sangat berguna mengenai hubungan antara variabel-variabel penelitian. Batas untuk menolak dan menerima yang diajukan adalah $>1.734$, dimana apabila $t$-statistic bernilai lebih kecil dari 1.734 maka hipotesis akan ditolak. Berikut adalah tabel output estimasi untuk pengujian model struktural.

Tabel 7

Path Coeffiecients

\begin{tabular}{|c|c|c|c|}
\hline Variabel & $\begin{array}{c}\text { Original } \\
\text { Sample }\end{array}$ & $\begin{array}{c}\text { Standar } \\
\text { d Error }\end{array}$ & $\begin{array}{c}\mathrm{T} \\
\text { Statistics }\end{array}$ \\
\hline $\begin{array}{c}\text { IC -> kinerja } \\
\text { keuangan }\end{array}$ & 0.916 & 0.039 & 23.243 \\
\hline $\begin{array}{c}\text { IC -> } \\
\text { pertumbuhan } \\
\text { perusahaan }\end{array}$ & 0.372 & 0.195 & 1.903 \\
\hline
\end{tabular}

Sumber: Output SmartPLS 3.0 2015

Pada model struktural pengujian hipotesis pertama yakni pengaruh intellectual capital sebagai variabel eksogen terhadap kinerja keuangan sebagai variabel endogen berpengaruh positif dengan nilai path coefficient sebesar 0.916 dan signifikan pada $\alpha=0.05$ dengan nilai $t$-statistic 23.243 lebih besar dari pada $t$ tabel 1.743. nilai positif pada koefisien korelasi sebesar 0.916 menunjukan bahwa hubungan antara variabel adalah sangat kuat.

Pada model struktural pengujian hipotesis kedua yakni pengaruh intellectual capital sebagai variabel eksogen terhadap pertumbuhan perusahaan sebagai variabel endogen berpengaruh positif dengan nilai path coefficient sebesar 0.372 dan signifikan pada $\alpha=0.05$ dengan nilai $t$-statistic 1.903 lebih besar dari pada t tabel 1.743. nilai positif pada koefisien korelasi sebesar 0.372 menunjukan bahwa hubungan antar variabel adalah cukup.

\section{HASIL DAN PEMBAHASAN}

Intellectual capital berpengaruh positif terhadap kinerja keuangan menunjukan bahwa perusahaan telah mampu memanfaatkan dan mendayagunakan modal fisik yang ada guna menciptakan nilai tambah (value added) untuk menghasilkan input (return) yang lebih besar. Hal ini menunjukan bahwa perusahaan memiliki kemampuan intellectual capital dalam memenuhi proses operasi perusahaan dalam rutinitasnya mampu mendukung karyawan yang akan menghasilkan kinerja intelektual dan kinerja bisnis yang optimal, serta mampu menjalin hubungan harmonis dengan mitra perusahaan melalui modal fisik yang ada. Menurut Solikhah (2010) perusahaan yang mampu mengelola sumber daya 
intelektualnya dengan efisien akan menciptakan value added dan competitive advantage yang akan bermuara pada peningkatan kinerja keuangan. hal ini sesuai dengan Resource-Based Theory yang mengatakan perusahaan akan mencapai keunggulan apabila memiliki sumber daya yang unggul.

Hasil pengujian hipotesis kedua membuktikan bahwa intellectual capital yang diukur menggunakan indikator value added intellectual coefficient (VAIC) berpengaruh positif terhadap pertumbuhan perusahaan yang diukur menggunakan indikator asset growth (AG) dan equity growth (EG) pada periode 2011-2013. Yang berarti semakin tinggi nilai intellectual capital perusahaan mengakibatkan meningkat juga nilai pertumbuhan perusahaan. Perusahaan yang mampu mengelola sumber daya intelektualnya dengan maksimal akan memperoleh value added secara teratur dan berkesinambungan sehingga perusahaan mampu untuk tumbuh dan tetap survive.

Pemanfaatan penuh atas sumber daya perusahaan baik sumber daya berwujud maupun tak berwujud akan mendorong keberhasilan pertumbuhan dan keberlangsungan perusahaan (Wernerfelt, 1984). Oleh karena itu, bukti empiris adanya pengaruh positif modal intelektual terhadap pertumbuhan sesuai dengan pandangan teori Resource-Based.

\section{SIMPULAN}

1. Intellectual capital berpengaruh positif terhadap kinerja keuangan. Hasil ini sesuai dengan yang dikatakan oleh Solikhah (2010) bahwa perusahaan yang mampu mengelola sumber daya intelektualnya dengan efisien akan menciptakan value added dan competitive advantage yang akan bermuara pada peningkatan kinerja keuangan. Dan sesuai dengan Resource-Based Theory yang mengatakan perusahaan akan mencapai keunggulan apabila memiliki sumber daya yang unggul.

2. Intellectual capital berpengaruh positif terhadap pertumbuhan perusahaan. Yang berarti bahwa perusahaan yang mampu mengelola sumber daya intelektualnya dengan maksimal akan memperoleh valua added secara teratur dan berkesinambungan sehingga perusahaan mampu untuk tumbuh dan tetap survive. Sesuai dengan yang dikatakan oleh Wernerfelt (1984) bahwa pemanfaatan penuh atas sumber daya perusahaan baik sumber daya yang berwujud maupun tidak berwujud akan mendorong keberhasilan pertumbuhan dan keberlangsungan perusahaan, dan sesuai dengan pandangan teori Resource-Based.

\section{Saran}

1. Untuk perusahaan agar dapat mengembangkan dan meningkatkan lagi efisiensi dari intellectual capital yang berupa efisiensi human capital dan structural capital sehingga perusahaan lebih dapat memaksimalkan value added. 
2. Penelitian ini hanya pada perusahaan publik yang terdaftar di BEI. Perusahaan yang tidak go public tidak terindikasi nilai intellectual capitalnya sehingga kemampuan dalam menghadapi persaingan dan untuk terus going concernnya tidak mudah ditemukan. Oleh karena itu penelitian selanjutnya diharakan memilih perusahaan diluar perusahaan yang terdaftar di BEI, sehingga generalisasi dan uji test-nya lebih kuat.

3. Penelitian selanjutnya disarankan agar memperpanjang periode penelitian, karena periode pengamatan dalam penelitian ini masih tergolong singkat, tiga tahun pelaporan sehingga sampel yang terpilih relatif kecil, serta menambahkan indikator-indikator lain dalam variabel yang diteliti. Ataupun mencari variabel lain yang juga memiliki hubungan dengan intellectual capital.

4. Untuk regulator, hasil dari penelitian ini diharapkan dapat memberi informasi dan kontribusi untuk pengambilan kebijakan terkait perlakuan intellectual capital yang sampai saat ini masih mempunyai masalah dalam pengukuran dan penilaian.

\section{DAFTAR PUSTAKA}

Anatan, L. 2004. "Modal Intelektual dan Kinerja Keuangan". Sebuah Review Aplikasi Manajemen Modal Intelektual dalam Era Manufaktur. Telaah Bisnis, Vol. 5 No.2

Agnes Sawir. 2005. Analisis Kinerja dan perancanaan Keuangan Keuangan Perusahaan. PT Gramedia Pustaka, Jakarta.

Appuhami, R. 2007. The Impact of Intellectual Capital on Investors Capital Gains on Shares: An Empirical Investigation of Thai Banking, Finance \& Insurance Sector. International Management Review, III (2): 14-25.

Barney, J.B. 1991. Organizational Culture: Can It Be A Source of Sustained Competitif Advantege?. Academy of Management Review. Vol 11, pp. 656665.

Chen, et al. 2005. An empirical investigation of the relationship between intellectual capital and firm's market value and financial performance. Journal of Intellectual Capital, Vol 6, Issue 2.

DeNisi, et al. 2003. "Managing Knowledge For Sustained Competitive Advantage". Available online: en.scientificcommons.org/42558655 - United State.

Hengki Latan dan Imam Ghozali., 2012. Partial Least Square Konsep, Teknik, dan Aplikasi Menggunakan Program SmartPLS 2.0 M3. Badan Penerbit Universitas Diponogoro. Semarang.

Husain Umar., 2003. Metodologi Penelitian Untuk Skripsi dan Tesis Bisnis. PT. Gramedia Pustaka. Jakarta.

Ihyaul Ulum. 2009. Intellectual Capital: Konsep dan Kajian Empiris, Graha Ilmu, Yogyakarta. 
Kallapur, Sanjay dan Trombley, Mark A. 1999. "The Association Between Investment Opportunity Set Proxies and Realized Growt". Journal of business \& Accounting. Vol. 26, April/May. pp 505-519.

Margaretha, Farah dan Arief Rakhman. 2006. Analisis Pengaruh Intellectual Capital Terhadap Market Value dan Financial Performance Perusahaan dengan Metode Value Added Intellectual Coefficient. Jurnal Bisnis dan Akuntansi Vol. 8, No. 2.

Njuguna, John I. 2009. "Strategic Positioning For Sustainable Competitive Advantage: An Organization Learning Approach". Journal of Business Management: Vol. 2, Issue 1.

Pulic, A. 1998. "Measuring the performance of intellectual potential in knowledge economy". Paper presented at the $2^{\text {nd }}$ Mcmaster word congress on measuring and managing intellectual capital by the Austrian Team for Intellectual Potential.

Solikhah, 2010. Implikasi Intellectual Capital terhadap Financial Performance, Growth dan Market Value; Studi Empiris dengan Pendekatan Simplistic Specification. Makalah disampaikan dalam Simposium Nasional Akuntansi XIII. Purwokerto.

Taswan, 2003. Analisis Integrasi Strategis di LIK dan Dividen terhadap Nilai perusahaan serta faktor-faktor yang mempengaruhunya. Jurnal bisnis dan ekonomi.

Tan et al. 2007. Intellectual capital and financial return of companies. Journal of Intellectual Capital Vol. 8 No. 1, pp 76-96.

Triwidodo, B., et al. 1997. ISO 9000 Untuk Kontraktor. P. P. Perumahan. PT. Gramedia Pustaka Utama, Jakarta.

Wernerfelt, B. 1984. A Resource Based View of the Firm. Strategic Management Journal, Vol. 5 No. 3,

Weston J. F. Dan Copeland T. E. 1997. Manajemen Keuangan. Edisi kesembilan, Terjemahan oleh A. Jaka Wasana MSM \& Kibrandoko MSM, Binarupa Aksara, Jakarta., etc.

\section{Situs Internet}

www.jpnn.com

www.pu.go.id

www.idx.co.id

$\underline{\text { www.tempo.co }}$ 